\title{
IAMJ
}

INTERNATIONAL

AYURVEDIC

MEDICAL JOURNAL

ISSN: 2320-5091

Impact Factor: 6.719

\section{AN INSIGHT OF IMPORTANCE OF DEEPANA \& PAACHANA IN PANCHAKARMA: CONCEPTUAL STUDY}

\author{
Ajay Kumar Yadav', Anup B Thakar ${ }^{2}$ \\ ${ }^{1}$ M.D. Scholar, Department of Panchakarma, ITRA, Jamnagar, Gujarat, India \\ ${ }^{2}$ Professor \& HOD, Department of Panchakarma ITRA, Jamnagar, Gujarat, India
}

Corresponding Author: ajayyadav21893@gmail.com

https://doi.org/10.46607/iamj1909072021

(Published Online: July 2021)

Open Access

(C) International Ayurvedic Medical Journal, India 2021

Article Received: 17/06//2021 - Peer Reviewed: 24/06/2021 - Accepted for Publication: 25/06/2021

\section{Check for updates}

\begin{abstract}
Panchakarma therapy is a unique clinical treatment done for bio-purification of the body. Both Shodhana (biopurification) and Shamana treatment (Pacification Treatment) modalities of Ayurveda place equal emphasis on Deepana and Paachana (appetizer-digestives). Deepana and Paachana karma plays important role in bringing the Sama dosha (dosha associated with ama) to Nirama (doshas without ama) state, as they mobilize the doshas from Shakha to koshtha and thus helps in easy expulsion of Doshas from the body. Deepana and Paachana Karma, as Purvakarma of Shodhana (bio-purification) procedures, are also essential. Purvakarma (preoperative procedure) refers to the body's preparation for Panchakarma procedures, and the body needs to achieve the full benefits of the treatments. Shodhana without Ama-Paachana results in further complications. As a result, the treatment is based on Srotoshodhana, Paachana, Agnideepana, and Vatanulomana. Objective: The objective is to extensively explore the concept of Deepana \& Paachana and elicit its applied aspect in Panchakarma therapy. Data Source: All the available information related to Deepana \& Paachana is mentioned in classical texts primarily in Charaka Samhita and its related Commentaries, articles, Journals. Review Methods: The information related to Deepana \& Paachana and its judicious use in Panchakarma are reviewed by comparing and analysing the different aspects of both classical tests and allied commentaries as well as contemporary authors. Conclusion: The concept of Deepana \& Paachana here has been studied analytically in the radiance of proper and judicious Panchakarma practices to elicit its utility in better treatment.
\end{abstract}


Keywords: Deepana, Paachana, Panchakarma, Purvakarma.

\section{INTRODUCTION}

Most of the Shodhana therapies are administered through the gastrointestinal tract, hence optimal functioning of this system is essential for the effective administration of these therapies. Optimal functioning may be achieved by Purvakarma before administration of any Shodhana procedure, they prepare the body and make the Dosha fit to be eliminated. therefore, Paachana Chikitsa is categorized as one among the Purvakarma. After Deepana Paachana the Dosha is ready to be expelled. As per Acharya Hemadri commenting Paachana does digestion of Ama, Deepana does separation of Dosha from Dhatu, Snehana does Utkleshana of Dosha and Swedana bring Dosha from Sakha to Koshtha. ${ }^{2}$ DeepanaPaachana is the primary therapy for digestion of Ama (impaired metabolic) by rectification of Agni (digestive fire). If the Agni is good then the person is healthy, if there is any vitiation of Agni then the person will be diseased, and if there is no Agni then the person will die so Agni plays an important role in life. ${ }^{3}$ Lord Krishna defines the importance of Agni by saying- having become the fire Vaisvaanara, I abide in the body of living beings and, associated with the Prana and Apana, digest the fourfold food. ${ }^{4}$ Agni in the context of the functioning of a living organism, which maintains its integrity and performs its vital activities by converting the food consumed not only into its various structural and functional constituents but also to provide Shakti or energy necessary for proceeding with its innumerable vital activities. ${ }^{5}$

For this reason, Ayurvedic treatment modalities are constantly focused on restoring the normal condition of Agni. Among all Agni, Jatharagni is directly related to Dhatvagni or bioenergy in the cells and their metabolic processes, with ultimate tissue metabolism or Dhatu-Paka process and all the Dhatvagni depend on the normal, healthy state of Jatharagni. ${ }^{6}$

Disturbed Agni leads to disturbed homeostasis resulting in impaired catabolism and anabolism resulting in impaired immunity emissions of desecrated products leading to metabolic waste collection. All of this con- tributes to Ama being formed, leading to metabolic disorders. In such conditions cleansing of channels is essential through eliminating the Margavrodha (route- obstruction) due to Ama which is accumulated in the body due to Mandaagni (weak digestion). In this condition Amapaachana (digestion of undigested material waste) should be done thus DeepanaPaachana therapy is very significant for this $\mathrm{Ag}$ nimaandya condition. There are several Ayurvedic drugs which are having these properties; termed Deepaniya and Paachaniya.

Aims \& Objective: The aims and objectives are to broadly discover and understanding the concept of Deepana\& Paachana therapy and elicit its applied aspect in Panchakarma considering our ancient Ayurveda classics.

Review Methods: The information related to Deepa$n a \&$ Paachana and its judicious application is reviewed by comparing and analysing the different aspects of both classicaltests

i.e. Brahuttrayi, Laghutrayi and allied commentaries as well as contemporary authors.

\section{Description of Deepana \& Paachana therapy: Deepana}

The procedure which does not Amapachana, but does Agni Deepana is called Deepana. ${ }^{7}$ The best Dravya for Deepana is Mishi according to Acharya Sharangdhara. According to Acharya Charaka there are Deepaniya Dasemani i.e. Pippali, Pippali Mula, Chavya Chitraka, Srngavera, Amlavetasa, Maricha, Ajamoda, Bhallataka Asthi and Hingu Niryasa. ${ }^{8}$

\section{Mode of Action of Deepana Dravya}

Deepana dravyas act in the following way in kindling the digestive fire.

1. Stimulation of Vagus nerve.

2. Stimulation of glossopharyngeal nerve.

3. Stimulation of fundus and pylorus.

The deepana dravyas due to their bitter taste promotes gastric juice and facilitate digestion. These drugs sensitize oral taste receptors and thus facilitating saliva secretion. They also induce gastrin secretion, a hor- 
mone that stimulates hydrochloric acid secretion.

improves Abhyavaharana Sakti (intake capacity). Deepana Dravya acts better on empty stomach. It

Table 1: Predominant Rasa in Deepana ${ }^{9}$

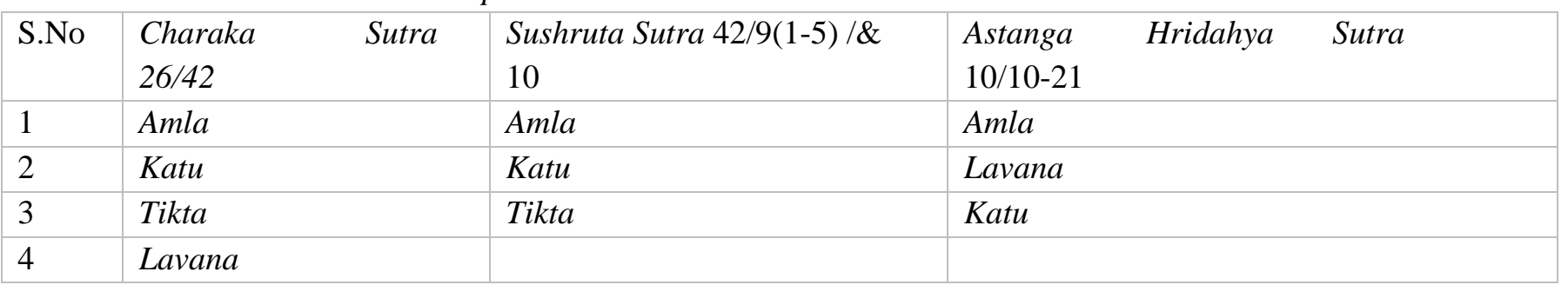

\section{Paachana (Digestives)}

The procedure which does Amapachana but does not do Agni Deepana is called Pachana. ${ }^{10}$

eg. Nagakesara. ${ }^{11}$

\section{Mode of Action of Pachana Dravyas}

1. Stimulation of the Vagus nerve which in turn secretes gastric juice.

2. Stimulates duodenum which leads to the secretion of digestive enzymes \& hormones.

3. Stimulates the liver to secrete bile.

4. Stimulates pancreas to secrete pancreatic juice.

It is beneficial in diseases like Agnimandhya, Ajirna, Grahani, Amavata etc. It increases Jarna Sakti (Digestion capacity). The drugs which are having both properties are called Deepana and Paachana drugs. eg. Chitraka so we conclude that Deepana-Paachana (appetizer- digestives) drugs Agni Mahabhoot (Elements) are predominant. Deepana and Paachana be- ing Langhana Chikitsa (the procedure which brings aboutlightness in the body) have the predominance of Laghu (light) Guna along with Ushna (hot), Tikshana (sharp) Sukshma (subtle), Ruksha (dry), Vishada (clear), Khara (rough), Sara(mobile) and Kathina (hard). ${ }^{12}$ Agni Mahabhoota (Fire element) of Deepana drugs possess the Guna like Ushna (hot), Tikshana (sharp), Sukshma (subtle), Vishada (clear)etc. and Vayu Mahabhoota(air element) possess Laghu (light), Sheeta (cold), Ruksha(rough) Guna. Due to these properties, the drug helps to change Sama Dosha (dosha in balance) to Nirama (without ama) Dosha.

Paachana Drugs According to Dosha (Chikitsa kalika).

1. Vata Vikara-Rasna Kvataha, Nagara Kvatha.

2. Pitta Vikara- Patola Kvatha, Vasa Kvatha.

3. Kapha Vikara- Nimba Kavtha, Triphala Kvatha.

Table 2: Predominant Rasa in Paachana ${ }^{13}$

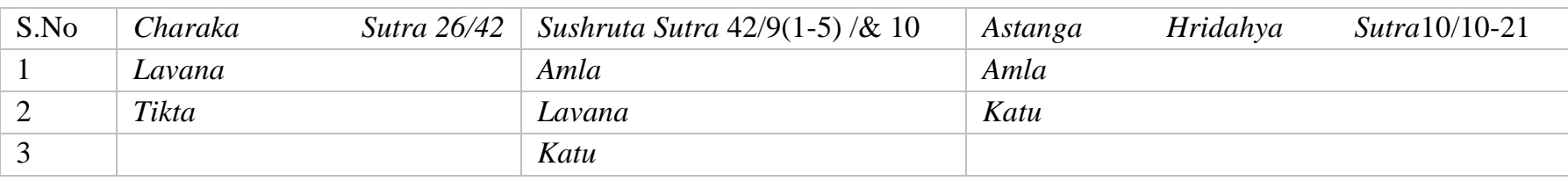

\section{Role of Deepana- Paachana In Panchakarma}

Panchakarma is the composite nomenclature of five kinds of treatments designed for bio- purification of the body. Panchakarma is essentially the therapeutic technology of Samshodhana. Classical texts have described Panchakarma therapy into three main karmas as Purva Karma, Pradhana Karma and Paschata karma. $^{14}$ The first and foremost karma did in every Panchkarma therapy is Purva karma.

\section{Duration of Deepana and Pachana Chikitsa:}

Overall, there seems to be no mention of how long Deepana and Paachana should be executed until the Samyak Lakshana of Langhana is seen in the classics. The Samyak Langhana Lakshana includes proper Vata, Mutra, and Purisha elimination, a sense of lightness in the body, a sense of purity in the chest, belching, throat, and mouth, the disappearance of drowsiness and exertion, the appearance of sweat and 
a taste for food, and the appearance of hunger and thirst. $^{15}$

\section{What Is the Need for Purva Karma?}

1. It promotes Agni, the bio-fire.

2. It exhausts Ama, the morbid dosha in situ.

3. It mobilizes the dosha from shakha to koshtha.

4. It softens the body parts and renders the cells and tissues more washable.

In Purva Karma Deepana and Paachana are essential procedures for all panchakarma therapies. All diseases according to Ayurveda are due to vitiated Agni and Ama is the main factor for vitiation of Agni. Deepana and Paachana drugs prepared the body for Panchakarma procedure by removing the Srotorodha (opening of channel) through digestion of Ama. According to Acharya Hemadri Paachana drugs does the digestion of Ama and Deepana (appetizer) does the separation of Dosha from Dhatu. Both drugs help to bring the Sama condition to Nirama condition, and it is very beneficial for Shodhana(purification) because spread it all over the body and should not eliminate because, if one tries to remove Sama Dosha, which is deeply seated and strongly bind to Dhatu. Shodhana will destroy the body by extracting juice from unripe fruit ${ }^{16}$. So, at first, we should be prepared the body with Pachana (digestive), Deepana afterwards by Shodhana.

procedure (Purification therapy) the morbid Dosha expel out at proper time through nearest possible route according to strength.

Importance and Mode of action of Deepana- Pachana

The concept of Ama (metabolic waste material) and Agni (digestive fire) is exclusive in Ayurveda, it finds a place in the genesis of almost all diseases and their management. Ama associated itself with Vata, moves quickly to the different seats of Kapha in the body filling them and the Dhamani (arteries) with a waxy material. ${ }^{17}$ Thus the product of digestion associated with Vata Pitta and Kapha in assuming different colours, blocks the tissue pores and passages with a thick waxy material. Properties of Ama include Apakti (indigestion), Gaurava (Heaviness), Bala Bhransha (weakness), Mala Sanga (Constipation), Strotorodha
(Blockage of the channels) and Anila-Mudhta (Stiffness) ${ }^{18}$ indicates that Ama exists in an incomplete metabolic state i.e., incompletely digested or metabolized form of food. Similarly, free radicals are an atom/molecule that contains one or more unpaired electrons, which requires neutralization by antioxidants. This destruction may lead to putrefaction and foul smell generations which are like one of the properties of Ama described as Durgandham ${ }^{19}$.

\section{An overview of Classical texts related to Deepana} \& Paachana.

Deepana and Paachana were correctly identified as crucial roles in Chikitsa by Acharya Sharangdhara, who described it in the Prathama Khanda. In the 5th Chapter, Acharya Dalhana mentions Deepana and Paachana as Purvakarma. According to Acharya Vagbhata, Deepana and Paachana are listed under Sapta Vidha Shamana, but Acharya Charaka does not mention Deepana and only mentions Paachana under Dasha Vidha Langhana. Dravyas that are both Deepana and Paachana are found in the Deepaniya Dashemani, and Paachana Dravyas also brings about Agni Deepti. Thus, Deepana is not explained separately in Dasha Vidha Langhana.

\section{CONCLUSION}

In the present era due to sedentary lifestyle, a chance of disturbance of Agni is more at the level of Jatharagni and ultimately the Dhatvagni and Bhootagni also get disturbed. Deepana and Paachana dravyas play an important role in bringing Sama to Nirama state. Thus, deepana Paachana is highly efficient as Purva karma in Samsodhana karma and Shamana Karma.

\section{REFERENCES}

1. Sushrut Samhita of Maharshi Sushruta with Nibandhsamgraha Commentary by Shri Dalhan edited by Yadav Ji Trikamji Acharya, reprinted 2017, New Delhi, Chaukhamba Publications, Sutra Sthan, $5^{\text {th }}$ Adhyaya, $3^{\text {rd }}$ verse, page no. 18.

2. Ashtang Hridya of Acharya Vagbhata with the commentaries of Sarvangasundara of Arundatta and Ayurvedarasayana of Hemadri, edited by Pt Hari Sadashiva Shastri, reprinted 2018, New Delhi, Chaukhamba Pub- 


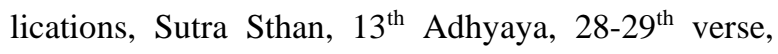
page no 217

3. Charaka Samhita of Agnivesha elaborated by Charaka and Dridhabala, Charaka Samhita with Ayurveda Dipika Commentary by Chakrapanidatta, edited by Yadav Ji Trikamji Acharya, reprinted 2014, New Delhi, Chaukhamba Publications, Chikitsa sthana, $15^{\text {th }}$ Adhyaya, 3-4 $4^{\text {th }}$ verse, page no. 512.

4. Vedvyasa, Shrimad Bhaagvat geeta, Geetapress, 41th edition, Gorakhpur, Samvat 2045, Chapter 15 verse 14, p.331.

5. Charaka Samhita of Agnivesha elaborated by Charaka and Dridhabala, Charaka Samhita with Ayurveda Dipika Commentary by Chakrapanidatta, edited by Yadav Ji Trikamji Acharya, reprinted 2014, New Delhi, Chaukhamba Publications, Sutra sthana, $27^{\text {th }}$ Adhyaya, 349-350 th verse, page no. 174.

6. Akash Kumar Agrawal, C. R. Yadav, and M. S. Meena, Physiological aspects of Agni, Ayu,2010JulSep;31(3):395-398.

7. Sharngadhar, Sharngdhar Samhita with Jiwanprada Hindi Commentary by Dr Smt. Shaileja Srivastava, Edition: Reprint, Chapter 4 verse 1, Varanasi, Chaukhambha Orientalia 2011, p.30

8. Charaka Samhita of Agnivesha elaborated by Charaka and Dridhabala, Charaka Samhita with Ayurveda Dipika Commentary by Chakrapanidatta, edited by Yadav Ji Trikamji Acharya, reprinted 2014, New Delhi, Chaukhamba Publications, Sutra sthana, $4^{\text {th }}$ Adhyaya, 9 ${ }^{\text {th }}$ verse, page no. 32

9. Bhavya BS, Pampanna Gouda H. A Literary Review on concepts of Deepana and Paachana. J of Ayurveda and Hol Med (JAHM); 2014;2(7)

10. Sharngadhar, Sharngdhar Samhita with Jiwanprada Hindi Commentary by Dr Smt. Shaileja Srivastava, Edition: Reprint, Poorva khand, Chapter 4 verse 2, Varanasi, Chaukhambha Orientalia, 2011; 30.

11. Charaka Samhita of Agnivesha elaborated by Charaka and Dridhabala, Charaka Samhita with Ayurveda Dipika Commentary by Chakrapanidatta, edited by Yadav Ji Trikamji Acharya, reprinted 2014, New Delhi, Chaukhamba Publications, Sutra sthana, $22^{\text {nd }}$ Adhyaya, $10^{\text {th }}$ verse, page no. 120.

12. Sushrut Samhita of Maharshi Sushruta with Nibandhsamgraha Commentary by Shri Dalhan edited by Yadav Ji Trikamji Acharya, reprinted 2017, New Delhi, Chaukhamba Publications, Sutra Sthan, $5^{\text {th }}$ Adhyaya, $3^{\text {rd }}$ verse, page no. 18 .

13. Bhavya BS, Pampanna Gouda H. A Literary Review on concepts of Deepana and Paachana. J of Ayurveda and Hol Med (JAHM); 2014;2(7)

14. Ashtang Hridya of Acharya Vagbhata with the commentaries of Sarvangasundara of Arundatta and Ayurvedarasayana of Hemadri, edited by Pt Hari Sadashiva Shastri, reprinted 2018, New Delhi, Chaukhamba Publications, Sutra Sthan, $13^{\text {th }}$ Adhyaya, 28-29 ${ }^{\text {th }}$ verse, page no 217

15. Charaka Samhita of Agnivesha elaborated by Charaka and Dridhabala, Charaka Samhita with Ayurveda Dipika Commentary by Chakrapanidatta, edited by Yadav Ji Trikamji Acharya, reprinted 2014, New Delhi, Chaukhamba Publications, Sutra sthana, 22 ${ }^{\text {nd }}$ Adhyaya, $34^{\text {th }}$ verse, page no. 122

16. Priyanka Nandkishor Kalbende et al; review article on Consideration of ama as a causative entity of some diseases a review as per Ayurveda, jipbs, vol 3 (2), 5458, 2016

17. Ashtang Hridya of Acharya Vagbhata with the commentaries of Sarvangasundara of Arundatta and Ayurvedarasayana of Hemadri, edited by Pt Hari Sadashiva Shastri, reprinted 2018, New Delhi, Chaukhamba Publications, Sutra Sthan, $13^{\text {th }}$ Adhyaya, 23-24 $4^{\text {th }}$ verse, page no 216

18. Ashtang Hridya of Acharya Vagbhata with the commentaries of Sarvangasundara of Arundatta and Ayurvedarasayana of Hemadri, edited by Pt Hari Sadashiva Shastri, reprinted 2018, New Delhi, Chaukhamba Publications, Sutra Sthan, $13^{\text {th }}$ Adhyaya, $25^{\text {th }}$ verse, page no 217

19. Madhavakara, Madhav Nidan, The Madhukosha Sanskrit Commentary by Sri Vijayraksita and Srikanthadatta and The Vidyotini Hindi Commentary by Sri Sudarsana Sastri, Edited by Prof.Yadunandan Upadhyaya, (M.N 25/1), Chaukhambha Prakashana, Revised Edition Reprint-2009, Varanasi, $3^{\text {rd }}$ Adhyaya, $12^{\text {th }}$ verse, page no 25

\section{Source of Support: Nil Conflict of Interest: None Declared}

How to cite this URL: Ajay Kumar Yadav \& Anup B Thakar: An Insight Of Importance Of Deepana \& Paachana In Panchakarma: Conceptual Study. International Ayurvedic Medical Journal \{online\} 2021 \{cited July 2021\} Available from:

http://www.iamj.in/posts/images/upload/1447_1451.pdf 